\title{
Feeding of Azolla as a Green Fodder Feed Supplement on Productive Performance and Milk Composition of Crossbred Dairy Cows in Theni District of Tamil Nadu, India
}

\author{
A. Senthil Kumar*, S. Murugesan and P. Balamurugan \\ Farmers Training Centre,Tamil Nadu Veterinary and Animal Sciences University, \\ Theni- 625531, India \\ *Corresponding author
}

\section{A B S T R A C T}

\begin{tabular}{|l|}
\hline Ke y w or d s \\
$\begin{array}{l}\text { Azolla-Dairy cattle- } \\
\text { Milk production } \\
\text { and milk fat } \\
\text { Composition }\end{array}$ \\
\hline Article Info \\
\hline $\begin{array}{l}\text { Accepted: } \\
18 \text { May } 2020 \\
\text { Available Online: } \\
10 \text { June } 2020\end{array}$ \\
\hline
\end{tabular}

Crossbred dairy cattle milk production and milk fat depends mainly on feeding management with adequate availability of nutrients in their feed materials. It comprises the major protein supply for milk production. The demand of milk is increasing for nutrition of population in country. Presently, Azolla green fodder feeding is being considered essential for lactating dairy animals. Azolla is nothing but floating fern in shallow water, which is very rich in protein, essential amino acids, and vitamins. Azolla can be easily digested by the dairy animal because of its high protein and low lignin content, green Azolla can be used as feed supplement for the milch animals (500-1000gm per day) which could increase the milk production by $7-13 \%$. The front line demonstration of Azolla cultivation in the programm area could bring changes in feeding management of dairy cattle.

\section{Introduction}

In India, Theni District of Tamil Nadu has a huge dairy cattle population, dairy farming main farming activity next to agricultural activity, yet the production of milk and other milk products are the lowest in Theni District. One of the main reasons for the low productivity of Dairy cattle is unbalanced nutrition or poor nutrition or both, besides the medium genetic potential of the animals. To achieve the goal of improving productivity of dairy cattle would be the streamlining of balanced nutrition. Most of our dairy farmer fed their dairy cows with low protein content of feed because of high cost of oil cakes. Feed alone represent 70-75 per cent of total cost of production. Availability of quality feed at a reasonable price is a key to a sustainable and profitable dairy production system. 
Intensive and semi intensive system of dairy Farming has prompted many farmers and innovative techniques to improve the productivity of their dairy animals. Azolla (Azolla pinnata), a floating water fern, is an unconventional feed ingredient as it is not accepted by most of the dairy owners. They consider it a noxious weed (Lumpkin et al., 1980). Adaption of Azolla in India has been slow and sporadic due to poor yield, pest handling and storage difficulties and labour difficulties (Tamizhkumaran and Rao, 2012).

It grows naturally in stagnant water of drains, canals, ponds, rivers and marshy lands (Basak et al., 2002). It is most economic and efficient feed substitute for dairy animals and increases milk production in animal (Pannaerker, 1988). Azolla is rich in protein, essential amino acids, carotinoids, vitamins, growth promoters and minerals (Basak et al., 2002) and contains $20.0-25.5 \%$ protein, $3.1 \%$ fat, $34.9 \%$ carbohydrates, $8.5-11.7 \%$ cellulose and essential amino acids (Sithara and Kamalaveni, 2008).

Carbohydrates and oil contents are very low in Azolla. High protein and low lignin content contribute for its high digestibility by dairy cows. Azolla may serve as a valuable protein supplement for many species (Hasan and Chakrabarti, 2009). Besides dairy animals, it may be supplemented in feed for sheep, goat, pig, rabbits and poultry. (Singh and Subudhi, 1978; Basak et al., 2002; FAO,2011).

In present scenario, the dairy farmers are dependent on commercial feeds, which are not economical for dairy milk production. Studies on Azolla supplementation in cattle are scanty; therefore, the present study was aimed to assess the effects of Azolla feeding on milk production performance and milk composition of cattle so that the possibility of Azolla as a low cost green fodder feed ingredient is explored.

\section{Materials and Methods}

Dairy farmers of Pasumalaitheri, Kelapusanuthu and Bhatrakalipuram villages in Theni District were given proper training on Azolla cultivation through Front line demonstrations. Azolla plot was established at selected Farmers field and they were motivated on feeding Azolla to their milch animals.

Cultivation and feeding of Azolla was taken up by all category of farmers irrespective of them having animals of different breed and stage of their growth. Harvested Azolla was thoroughly washed with fresh water to remove the dung smell.

To study the impact of feeding of azolla , totally $45(\mathrm{n}=45)$ dairy lactating cows (Jersey /HF crossbreds) second to fourth lactation were selected from above mentioned three villages in Kadamalaigundu and Bodi block of district for the period of 4 months in September to December 2015.

All selected 45 animals were taken as treatment group, they are equally divided in to three groups each group having 15 numbers of animals. Before supplementation azolla all 45 animals as taken control, the milk yield and fat percentage data were collected for period of 2 months.; first group was fed with fresh Azolla 500 gm/day + regular level of commercial concentrate feeding + green fodder: second group fed with Azolla 1000 gm/day + regular level of commercial concentrate feeding + green fodder and third group animals fed with Azolla $2 \mathrm{~kg}$ gm/day + own concentrate feeding without cake items + green fodder/day.

All the animals were monitored daily for milk yield during 2 months period of supplementation. The animals were maintained under proper managemental 
conditions. Animals are kept in Pucca House. Separate feed mangers were provided. Animals were duly vaccinated and dewormed. Animals were milked twice daily (5 am and 5 pm) by full hand milking. Milk yield was measured by measuring cylinder and measuring flask. Record was maintained on register for individual cows.

Table.a Feeding the animal with azolla

\begin{tabular}{|c|c|c|}
\hline Group & Treatment & Period of feeding \\
\hline & Control $(n=45)$ & 2 months \\
\hline $\begin{array}{c}I \\
(n=15)\end{array}$ & $\begin{array}{c}\text { Azolla } 500 \mathrm{gm} / \text { day }+ \text { regular level of commercial } \\
\text { concentrate feeding }+ \text { green fodder }\end{array}$ & 2 months \\
\hline $\begin{array}{c}\text { II } \\
(n=15)\end{array}$ & $\begin{array}{l}\text { Azolla } 1000 \mathrm{gm} / \text { day }+ \text { regular level of commercial } \\
\text { concentrate feeding }+ \text { green fodder }\end{array}$ & 2 months \\
\hline $\begin{array}{c}\text { III } \\
(\mathbf{n}=\mathbf{1 5})\end{array}$ & $\begin{array}{c}\text { Azolla } 2 \mathrm{~kg} \mathrm{gm} / \text { day }+ \text { own concentrate feeding without } \\
\text { cake items }+ \text { green fodder/day }\end{array}$ & 2 months \\
\hline
\end{tabular}

\section{Results and Discussion}

The results of milk yield and milk fat percentage of different groups were presented in Table No.1. After azolla supplementation group I, II and III, the milk yield were $7.4 \pm$ $0.023 ; 7.7 \pm 0.035$ and 7.10. \pm 0.040 respectively. The milk fat percentage group I, II and III 3.7 $\pm 0.021 ; 3.8 \pm 0.028$ and 3.45 . \pm 0.018 respectively. After azolla feeding, the increase in milk yield and milk fat of the three groups were 0.3 and 0.5 litre; 0.3 and 0.9 litre and 0.02 and 0.1 litre respectively.

The percentage of an average increased milk yield in this study was 7 to 13 per cent. Present finding in the value of milk production agreed with Nidhi et al., (2015) who reported that Azolla-fed group showed a significant increase of $11.85 \%$ in milk production. The results of present study near to close agreed with Pillai et al., (2005) who reported that fresh Azolla increased 10-15\% milk production in dairy cattle and saved 20 $25 \%$ of commercial regular feeds.

Increase in milk production might be due to high protein and minerals content of Azolla with low lignin content that contribute for better digestibility and nourishment. Azolla is efficient dairy cattle feed and is rich in protein, essential amino acids, carotenoids, vitamins, growth promoters and minerals (Basak et al., 2002). The observation in the present study is not accordance with Khare et al., (2014) who reported that when Azolla replaced mustard oil cake in lactating cow, there was increase in milk yield. But in this study, without oil cake in the ration, there is no increase of milk yield and fat per cent.

Present finding in the value of milk production is lower than the observation of Gauri et al., (2012) and Ambade (2010) there is milk yield increase by 15 to $20 \%$ after feeding of azolla in the diet of dairy cows and 15 to $20 \%$ commercial feed can be replaced with azolla. The profitability was comparatively higher in Azolla supplemented dairy cows due to significant higher milk yield against half replaced commercial feed.

The result of present study revealed that after azolla feeding with regular feeding ration the procurement of milk rate raised from Rs.26 to 28 rupees due to increase the milk fat per cent and additional amount of milk yield 0.7 litre per day. 
So farmers were got in additional income Rs 30 per day. Farmers, feeding their cows with Azolla $2 \mathrm{~kg}$ and Regular Concentrate feeding without oil cakes and Green fodder were got in additional income Rs 25 per day through the oil cake purchase cost. But no change in milk fat and milk yield. Economics of this study revealed on debit side additional cost Rs: 830.00 for making Azolla plot per year and credit side additional returns Rs 30.00 per day.
Green fodder is not available in summer season due to lack of irrigation. It is observed that azolla feeding practice has a good result at the level of small farmer; they get an opportunity to feed azolla round the year. Besides this, it is less costly to get protein rich food for their animals easily. Animal owners who used to spend more money to feed their animals by purchasing ready-made cattle feeds; for them, azolla cultivation worked as a cost saving approach.

Table.1 Effect of Azolla feeding on milk yield and fat percentage

\begin{tabular}{|c|c|c|c|c|c|c|c|}
\hline \multirow[t]{2}{*}{$\begin{array}{c}\text { Group } \\
(n=45)\end{array}$} & \multirow[t]{2}{*}{ Treatment } & \multicolumn{2}{|c|}{ Before feeding Azolla } & \multicolumn{2}{|c|}{$\begin{array}{l}\text { After feeding } \\
\text { Azolla }\end{array}$} & \multicolumn{2}{|c|}{ Improvement } \\
\hline & & Fat \% & $\begin{array}{l}\text { Milk yield } \\
\text { (L) }\end{array}$ & Fat $\%$ & $\begin{array}{l}\text { Milk } \\
\text { yield } \\
(\mathbf{L})\end{array}$ & $\begin{array}{c}\text { increase } \\
\text { in milk } \\
\text { fat }\end{array}$ & $\begin{array}{c}\text { increase } \\
\text { in milk } \\
\text { yield }\end{array}$ \\
\hline & Control $(n=45)$ & $\begin{array}{c}3.2 \\
\pm \\
0.041\end{array}$ & $\begin{array}{c}6.4 \\
\pm \\
0.023\end{array}$ & $\begin{array}{c}3.19 \\
\pm \\
0.014\end{array}$ & $\begin{array}{c}6.4 \\
\pm \\
0.041\end{array}$ & 0 & 0 \\
\hline $\begin{array}{c}I \\
(n=15)\end{array}$ & $\begin{array}{l}\text { Azolla } 500 \mathrm{gm} / \text { day } \\
\text { +Regular Concentrate } \\
\text { feeding and Green fodder }\end{array}$ & $\begin{array}{c}3.4 \\
\pm \\
0.044\end{array}$ & $\begin{array}{c}6.9 \\
\pm \\
0.033\end{array}$ & $\begin{array}{c}3.7 \\
\pm \\
0.021\end{array}$ & $\begin{array}{c}7.4 \\
\pm \\
0.023\end{array}$ & $0.3 \%$ & 0.5 litre \\
\hline $\begin{array}{c}\text { II } \\
(\mathrm{n}=15)\end{array}$ & $\begin{array}{l}\text { Azolla } 1000 \mathrm{gm}+\text { Regular } \\
\text { Concentrate feeding and } \\
\text { Green fodder }\end{array}$ & $\begin{array}{c}3.5 \\
\pm \\
0.033\end{array}$ & $\begin{array}{c}6.8 \\
\pm \\
0.043\end{array}$ & $\begin{array}{l}3.8 \pm \\
0.028\end{array}$ & $\begin{array}{c}7.7 \\
\pm \\
0.035\end{array}$ & $0.3 \%$ & 0.9 litre \\
\hline $\begin{array}{c}\text { III } \\
(n=15)\end{array}$ & $\begin{array}{l}\text { Azolla } 2 \mathrm{~kg}+\text { Regular } \\
\text { Concentrate feeding } \\
\text { without oil cakes and Green } \\
\text { fodder }\end{array}$ & $\begin{array}{l}3.43 \pm \\
0.028\end{array}$ & $\begin{array}{c}7.0 \\
\pm \\
0.038\end{array}$ & $\begin{array}{l}3.45 \pm \\
0.018\end{array}$ & $\begin{array}{l}7.10 . \pm \\
0.040\end{array}$ & 0.02 & 0.1 litre \\
\hline
\end{tabular}

Azolla feeding has been accepted by all categories of farmers irrespective of breed \& level of milk production. Most of the farmers are able to gain milk production from 0.5 to $0.9 \mathrm{Lt}$ of milk. It is also observed that 500 to 1000 gm Azolla is fed over and above the existing feeding per animal per day. The initial cost of establishing an Azolla pit of 40 sq ft to produce 0.8 to $1 \mathrm{Kg}$ azolla per day is around Rs. 830/-, whereas the milch animal provided with Azolla will give 0.5 to $0.9 \mathrm{Lt}$. of additional milk yield per day per animal. With this, the cow owner will be getting an additional income of Rs 1000/ per animal per month. Not only azolla increased milk production but also improved animal's health condition.

\section{References}

Ambade, R.B., Jadhav, S.N. and Phalke, N.B. 2010. Impact of Azolla as a protein supplement and its influence on feed utilization in livestock. Livestock Line, 4(4): 21-23.

Basak, B.; Pramanik, A.H; Rahmnan, M.S.; Tarafdar, S.U. and Roy, B.C. (2002).. Azoola (Azolla pinnata) as a feed 
ingrident inn broiler ration. Intl. J. of Poultry Sci., 1: 29-24.

FAO, (2011). Successes and failures with animal nutrition practices and technologies in developing countries. Proceeding of the FAO Electronic Conference, September 1-30, 2010, Rome, Italy, p.119.

Gauri-Mahadevappa, D., Sanganal-Jagadeesh, S., Gopinath, C.R. and Kalibavi C.M.2012. Importance of Azolla as a sustainable feed for livestock and poultry - A review. Agricultural Reviews, 33: 93-103.

Hasan, M.H. and Chakrabarti, R. 2009. Use of Algae and Aquatic Macrophytes as Feed in Smallscale Aquaculture - A Review. Food and Agriculture Organization of the United Nations, Rome, Italy

Khare, A., Baghel, R.P.S., Gupta, R.S., Nayak, S., Khare, V., Patil, A., Sharma, R., Tomar, R. and Singh V.P. 2014. Milk production of indigenous cattle fed supplements of mustard oil cake orazolla meal (Azolla filiculoides). Livestock Research for Rural Development, 26(4): Article \# 65. Retrieved August 12, 2015; http://www.lrrd.org/lrrd26/4/khar26065 .html

Lumpkin, T.A. and Plucknett, D.L.1980. Azolla: Botany, physiology and use as a green manure.Economic Botany, 34: $111-153$.

Nidhi, R., Kumari,k., Singh,f and Gilhare,V.R.,2015. Effect of azollasupplemented feeding on milk production of cattle and production performance of broilers. Applied Biological Research 17(2): 214-218.

Pannaerker, S. 1988. Azolla as a livestock and poultry feed. Livestock Advisor, 13: 2226.

Pillai, P.K., Premalatha, S. and Rajamony, S. 2005.Azolla: A sustainable feed for livestock. LEISAIndia, 21(3): 26-27.

Singh, P.K. and Subudhi, B.P.R. 1978. Utilisation of Azolla in poultry feed. Indian Farming, 27:37-39.

Sithara, K. and Kamalaveni, K. 2008. Formulation of low-cost feed using azolla as a protein supplement and its influence on feed utilization in fishes. Current Biotica, 2: 212-219.

Tamizhkumaran, J and Rao S.V.N. 2012. Why Cultivation of Azolla as cattle feed not sustainable ? Indian Journal of Dairy Science, 65 (4): 348 - 353

\section{How to cite this article:}

Senthil Kumar. A., S. Murugesan and Balamurugan. P. 2020. Feeding of Azolla as a Green Fodder Feed Supplement on Productive Performance and Milk Composition of Crossbred Dairy Cows in Theni District of Tamil Nadu, India. Int.J.Curr.Microbiol.App.Sci. 9(06): 13821392.doi: https://doi.org/10.20546/ijcmas.2020.906.171 